\title{
Modulation of oxidative stress and microinflammatory status by colloids in refractory dialytic hypotension
}

\author{
Guy Rostoker ${ }^{1 *}$, Mireille Griuncelli ${ }^{1}$, Christelle Loridon ${ }^{1}$, Thomas Bourlet ${ }^{1}$, Eric Illouz $^{2}$ and Abbes Benmaadi ${ }^{1}$
}

\begin{abstract}
Background: Intradialytic hypotension may adversely affect the outcome of chronic hemodialysis. Therapeutic albumin has powerful anti-oxidant and anti-inflammatory properties. We have recently shown that systematic colloid infusion during hemodialysis sessions improves hemodynamic parameters in most dialysis hypotensionprone patients unresponsive to usual of preventive measures.

We postulated that frequent hypotensive episodes may lead to a noxious inflammatory response mediated by oxidative stress induced by ischemia-reperfusion. The aim of this study was therefore to analyze the effect of $20 \%$ albumin and $4 \%$ gelatin infusions on oxidative stress and microinflammatory status in hypotension-prone patients unresponsive to usual preventive measures.
\end{abstract}

Methods: Prospective cross-over study (lasting 20 weeks) of routine infusion of $200 \mathrm{ml}$ of $20 \%$ albumin versus 200 $\mathrm{ml}$ of $4 \%$ gelatin in 10 patients with refractory intradialytic hypotension. We analyzed the effect of $20 \%$ albumin and $4 \%$ gelatin on microinflammatory status, oxidative stress, serum nitrite and nitrate levels by analysis of variance.

Results: A significant decrease in serum ceruloplasmin and serum C3 was observed during the albumin period ( $p$ $<0.05$, repeated measure ANOVA). A significant decrease in serum hydrogen peroxide was seen during albumin and gelatin administration ( $p<0.01$, repeated measure ANOVA) and a very large decrease in serum lipid peroxides was observed during the albumin period only ( $p<0.01$, Friedman test). Serum lactoferrin, serum proinflammatory cytokines and serum nitrite and nitrate levels remained stable during the different periods of this pilot trial.

Conclusions: We conclude that the improvement in microinflammatory status observed during colloid infusion in hypotension-prone dialysis patients may be related to a decrease in ischemia-reperfusion of noble organs, together with a specific reduction in oxidative stress by albumin.

Trial registration: ISRCTN 20957055

Keywords: dialytic hypotension, 4\% gelatin, 20\% hyperoncotic albumin, microinflammatory status, oxidative stress

\section{Background}

Intradialytic hypotension is the most common complication of hemodialysis, affecting up to $33 \%$ of patients. It interferes with patients' well being and prevents adequate dialysis and fluid removal [1-3]. Intradialytic hypotension has a negative impact on health-related quality of life and reduces patients' life expectancy, favoring underdialysis and increasing the risk of ischemia or

\footnotetext{
* Correspondence: rostotom@orange.fr

'Service de Néphrologie et de Dialyse, Hôpital Privé Claude Galien, 20 route de Boussy, 91480 Quincy sous Sénart, France

Full list of author information is available at the end of the article
}

infarction of noble organs such as the heart, brain and bowel [2-4].

Recent studies have shown that human albumin can be safely used in intensive care patients [5] and exerts powerful anti-oxidant properties [6]. It may also better restore volemia and arterial pressure than saline derivatives in dialytic hypotension-prone patients, especially those with cardiovascular disease $[7,8]$. We recently conducted a 20 -week a single-blind prospective cross-over pilot trial of systematic infusion of $20 \%$ albumin as compared to $4 \%$ gelatin in 10 hypotension-prone patients on long-term bicarbonate hemodialysis and unresponsive to
C Biomed Central

() 2011 Rostoker et al; licensee BioMed Central Ltd. This is an Open Access article distributed under the terms of the Creative Commons Attribution License (http://creativecommons.org/licenses/by/2.0), which permits unrestricted use, distribution, and reproduction in any medium, provided the original work is properly cited. 
cool dialysate associated with sodium and ultrafiltration profiling. We observed a potential benefit of systematic colloid infusion, especially $20 \%$ albumin, in this subset of patients [9]. We postulated that frequent episodes of hypotension may induce a noxious inflammatory response mediated by oxidative stress induced by ischemia-reperfusion.

The aim of the present study was to analyze the effect of systematic infusion of $20 \%$ albumin and $4 \%$ gelatin on micro-inflammatory status, oxidative stress, serum nitrates and nitrites in these hypotension-prone patients unresponsive to usual preventive measures.

\section{Methods}

\section{Patients and dialysis}

Ten patients (6 women, 4 men) undergoing chronic intermittent bipuncture bicarbonate hemodialysis three times per week on a Cimino-Brescia fistula were included.

All the patients gave their written informed consent to the study. Their median age was 71.5 years (range: 4591 years) and the median time spent on hemodialysis was 4 years (range: 1-9 years). The main characteristics of the patients are summarized in Table 1.

All the patients experienced a hypotensive episode more than once a week, as defined by a systolic pressure
$(\mathrm{SBP})<100 \mathrm{mmHg}$ or a fall in systolic pressure $>30$ $\mathrm{mmHg}$ associated with symptoms of hypotension. All the patients were at their optimal dry weight, as shown by normovolemia on echography of the inferior vena cava and echocardiography after a dialysis session or the following morning after an evening dialysis session $[10,11]$. Hemodialysis was performed using an Integra module (Hospal, Lyon, France), with ultrapure dialysate (bacterial content: $<0.1 \mathrm{CFU} / \mathrm{ml}$ and endotoxin content $<0.03 \mathrm{U} / \mathrm{ml}$; dialysis water supply from Gambro, Colombes, France); the blood flow rate was $250-300 \mathrm{ml} /$ min and the dialysate flow rate was $500 \mathrm{ml} / \mathrm{min}$.

Dialysate temperature, dialysate composition (505 A from Fresenius, Fresnes, France) and the sodium and ultrafiltration profiles did not differ between the four treatment periods. Details on the patients' clinical conditions are provided in a recently published article [9].

\section{Study protocol}

\section{Trial registration}

This trial received approval $\left(\mathrm{n}^{\circ} 02-017\right)$ from the ethics committee of Henri Mondor University Hospital and was registered with the French Agency for Drugs and Health Devices AFSSAPS ( $n^{\circ}$ 021059) and with ISRCTN register (reference 20957055).

Table 1 Characteristics of the patients

\begin{tabular}{|c|c|c|c|c|c|c|c|}
\hline$n^{\circ}$ & $\begin{array}{c}\text { Age } \\
\text { (year) }\end{array}$ & Gender & $\begin{array}{l}\text { Duration of } \\
\text { dialysis } \\
\text { (years) }\end{array}$ & $\begin{array}{l}\text { Cause of renal } \\
\text { failure }\end{array}$ & Dialysis membrane & $\begin{array}{l}\text { Modality } \\
\text { of } \\
\text { dialysis }\end{array}$ & Risks factors for dialysis hypotension \\
\hline 1 & 45 & $\mathrm{~F}$ & 9 & SLE & $\begin{array}{l}\text { Polysufone } \\
\text { (ARYLANE H4 - } \\
\text { Hospal) }\end{array}$ & $\begin{array}{l}4 \mathrm{~h} \times 3 / \\
\text { Week }\end{array}$ & $\begin{array}{l}\text { Long duration of dialysis ( } 9 \text { years), SLE still active treated } \\
\text { by steroïds and ciclosporin - Diastolic dysfunction }\end{array}$ \\
\hline 2 & 91 & $\mathrm{~F}$ & 2 & $\begin{array}{l}\text { Atherosclerotic } \\
\text { nephropathy }\end{array}$ & $\begin{array}{c}\text { Diacetate } \\
\text { (DICEA130-Baxter) }\end{array}$ & $\begin{array}{l}3 \mathrm{~h} \times 3 / \\
\text { Week }\end{array}$ & $\begin{array}{l}\text { Very old age, severe ischemic cardiopathy - Diastolic } \\
\text { dysfunction }\end{array}$ \\
\hline 3 & 67 & $\mathrm{~F}$ & 6 & $\begin{array}{c}\text { Interstitial } \\
\text { nephrotoxic } \\
\text { nephritis } \\
\text { (Ciclosporin) }\end{array}$ & PMMA (BKF16-Toray) & $\begin{array}{l}4 \mathrm{~h} \times 3 / \\
\text { Week }\end{array}$ & Cardiac graft for ten years-Diastolic dysfunction \\
\hline 4 & 87 & M & 2 & $\begin{array}{l}\text { Atherosclerotic } \\
\text { nephropathy }\end{array}$ & $\begin{array}{c}\text { Diacetate (DICEA } \\
\text { 150-Baxter) }\end{array}$ & $\begin{array}{l}3 \mathrm{~h} \times 3 / \\
\text { Week }\end{array}$ & $\begin{array}{l}\text { Very old age, severe ischemic cardiopathy-Diastolic } \\
\text { dysfunction }\end{array}$ \\
\hline 5 & 76 & M & 3 & $\begin{array}{l}\text { Diabetes melitus } \\
\text { type ॥ }\end{array}$ & $\begin{array}{c}\text { Triacetate } \\
\text { (TRICEA210-Baxter) } \\
\end{array}$ & $\begin{array}{l}4 \mathrm{~h} \times 3 / \\
\text { Week }\end{array}$ & $\begin{array}{l}\text { Old age, diabetes, pace-maker, panhypotuitarism - } \\
\text { Diastolic dvsfunction }\end{array}$ \\
\hline 6 & 84 & $\mathrm{~F}$ & 3 & $\begin{array}{l}\text { Renal and urologic } \\
\text { tuberculosis }\end{array}$ & $\begin{array}{l}\text { Diacetate (DICEA } \\
\text { 130-Baxter) }\end{array}$ & $\begin{array}{l}3 \mathrm{~h} 30 \times \\
3 / \text { Week }\end{array}$ & $\begin{array}{l}\text { Very old age, severe ischemic and valvular cardiopathy - } \\
\text { Diastolic dysfunction }\end{array}$ \\
\hline 7 & 71 & M & 5 & $\begin{array}{l}\text { Atherosclerotic } \\
\text { nephropathy }\end{array}$ & $\begin{array}{l}\text { Chemically modified } \\
\text { Acetate (SMC } 170 \text { - } \\
\text { Bellco) }\end{array}$ & $\begin{array}{l}4 \times 3 \mathrm{~h} / \\
\text { Week }\end{array}$ & $\begin{array}{l}\text { Old age, severe ischemic cardiopathy-Diastolic } \\
\text { dysfunction }\end{array}$ \\
\hline 8 & 72 & M & 1 & Myeloma & $\begin{array}{l}\text { Triacetate } \\
\text { (TRICEA210-Baxter) }\end{array}$ & $\begin{array}{l}3 \mathrm{~h} 30 \times \\
3 \text { Week }\end{array}$ & $\begin{array}{l}\text { Old age, severe ischemic cardiopathy, arythmia } \\
\text { secondary to atrial fibrillation - chemotherapy for } \\
\text { myeloma - Diastolic dysfunction }\end{array}$ \\
\hline 9 & 70 & $\mathrm{~F}$ & 7 & $\begin{array}{c}\text { Analgesic } \\
\text { nephropathy }\end{array}$ & $\begin{array}{l}\text { Diacetate (DICEA } \\
\text { 130-Baxter) }\end{array}$ & $\begin{array}{l}4 \mathrm{~h} \times 3 / \\
\text { Week }\end{array}$ & $\begin{array}{l}\text { Old age, long duration of dialysis ( } 7 \text { years), arythmia } \\
\text { secondary to atrial fibrillation-Diastolic dysfunction }\end{array}$ \\
\hline 10 & 50 & $\mathrm{~F}$ & 6 & $\begin{array}{l}\text { Autosomic } \\
\text { dominant polycystic } \\
\text { kidney disease }\end{array}$ & $\begin{array}{l}\text { PAN (NEPHRAL 300- } \\
\text { Hospal) }\end{array}$ & $\begin{array}{l}4 \mathrm{~h} \times 3 / \\
\text { Week }\end{array}$ & Binephrectomy - Diastolic dysfunction \\
\hline
\end{tabular}




\section{SRCTN-NAPN-20}

\section{Study design}

This was a randomized four-period cross-over study lasting 20 weeks. Patients were randomized to one of two treatment sequences (sequence 1 or sequence 2: Figure 1: see details of study protocol in reference 9).

Briefly, for sequence 1, after 35 days without treatment, the participants $(n=5)$ received an infusion of $200 \mathrm{ml}$ of $20 \%$ albumin (Vialebex, LFB, Les Ulis, France) (from day 0 to day 35), followed by a washout period of 35 days, on $4 \%$ gelatin infusion (Gelofusin, Braun medical, Boulogne, France). During the last period from day 70 to day 105 , the participants received systematic infusions of $200 \mathrm{ml}$ of $4 \%$ gelatin.

For sequence 2, the participants $(\mathrm{n}=5)$ received from day 0 to day 35 a systematic infusion of $200 \mathrm{ml} 4 \%$ gelatin, followed by a washout period from day 35 to day 70 on $4 \%$ gelatin infusion; during the last period the participants received systematic infusions of $200 \mathrm{ml}$ of $20 \%$ albumin.

Systematic infusion of $200 \mathrm{ml}$ of $4 \%$ gelatin was required during the wash-out period by the ethics committee, to avoid noxious consequences of dialytic hypotension; the aim of this wash-out period was to avoid a carry-over effect of $20 \%$ albumin.

\section{Outcome measures}

The primary outcome measure was arterial pressure regulation and secondary outcome measures were nutritional status, ultrafiltration rate and dialysis quality, as recently reported [9]. Other secondary outcome measures, which included the effect of $20 \%$ albumin and $4 \%$ gelatin on microinflammatory status, oxidative stress, and serum nitrate and nitrite levels, are the subject of this study.

Study of microinflammatory status, oxidative stress, and serum nitrite and nitrate levels Serum and plasma samples were prepared before and at the end of the last dialysis session in each of the four protocol periods. We analyzed micro-inflammatory status by measuring Creactive protein, $\mathrm{C} 3$, haptoglobin and ceruloplasmin by nephelemetry (Minineph kits, The Binding Site Ltd; Saint-Egrève, France). We measured serum lactoferrin as a marker of polymorphonuclear neutrophil activation during dialysis sessions by using a home-made ELISA with rabbit anti-human lactoferrin and purified human lactoferrin purchased respectively from Biodesign International (Saco, USA) and Sigma-Aldrich (Saint Quentin Fallavier, France). We measured serum proinflammatory cytokines (IL1 beta, IL6, IL8, TNF alpha) as markers of monocyte activation during dialysis sessions, after blood

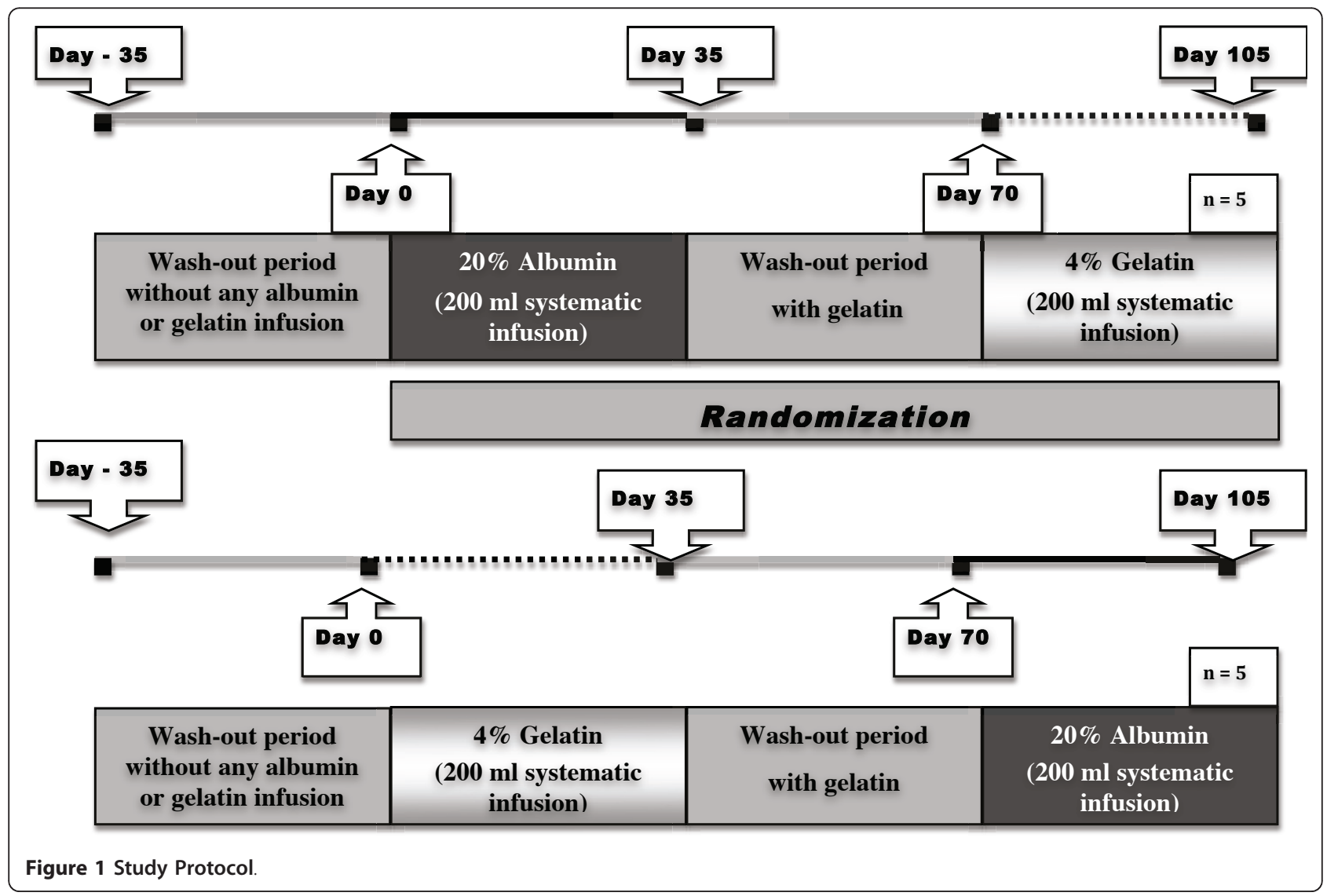


collection in endotoxin-free tubes (Endo Tube ET, Chromogenix; Vienna, Austria), using ELISA kits ( $\mathrm{R}$ and D systems; Lille, France). We analyzed oxidative stress by measuring circulating hydrogen peroxide and total lipid peroxides with colorimetric assays (Hydrogen Peroxide Kit, Assay Designs, Inc; Ann Arbor, USA and Per Ox Assay, Immunodiagnostik, Orange Medical, Brussels, Belgium). We measured nitrotyrosine, a stable endproduct of peroxynitrite oxidation, as a marker of NOdependent damage in vivo, by using an ELISA method (HyCult biotechnology, Tebu-bio; Le Perray en Yvelines, France). We also analyzed the total antioxidant power of plasma after uric acid depletion (using rasburicase, 2.5 $\mu \mathrm{L} / 100 \mu \mathrm{L}$ of serum for one hour at $30^{\circ} \mathrm{C}$ : Fasturtec 1.5 $\mathrm{mg} / \mathrm{ml}$, Sanofi-Synthelabo, Paris France) by using a colorimetric assay based on the evaluation of $\mathrm{Cu}^{+}$derived from $\mathrm{Cu}^{++}$by the combined action of all antioxidants in the sample (Oxford Biomedical Research, Oxford, UK).

As NO has been implicated in the pathophysiology of dialytic hypotension, we measured serum nitrite and nitrate levels by spectrophotometry, based on the Griess reaction after extensive centrifugation of the samples at $4^{\circ} \mathrm{C}$ on Biomax-PB Ultrafree-MC centrifugal filter units with ultrafiltration membranes with a cut-off of 10000 NMWL (Millipore, Saint-Quentin en Yvelines, France) and enzymatic conversion of nitrate to nitrite by nitrate reductase (Nitric oxide ( $\left.\mathrm{NO}^{-} / \mathrm{NO}^{-}\right)$assay ( $\mathrm{R}$ and $\mathrm{D}$ systems; Lille, France).

Statistical analyses We analyzed the effect of albumin and gelatin infusions on arterial pressure regulation (primary outcome measure), i.e. SBP (systolic blood pressure) and DBP (diastolic blood pressure), and the number of hypotensive episodes (defined as SBP $<100$ $\mathrm{mmHg}$, regardless of symptoms) and changes in the ultrafiltration rate and interdialytic weight gain (posthoc analyses) in each individual (in both regular and additional dialysis sessions) by the $\mathrm{n}$-of- 1 trial methodology implemented with the Wilcoxon test. We also analyzed the effect of the colloids on dialysis quality (single pool $\mathrm{Kt} / \mathrm{V}$, ionic dialysance 30 minutes before the end of the dialysis session, decrease in relative blood volume) and nutritional parameters (serum albumin and prealbumin) by analysis of variance (see details in reference 9 ).
Changes in microinflammatory status, oxidative stress, serum cytokine, lactoferrin, nitrate and nitrite levels during the four periods of the protocol were analyzed with either parametric or non parametric analysis of variance followed by post-tests depending on the normality of the distribution (in the Kolmogorow-Smirnov test) [12] using Prism 4 software (Graphpad, San Diego, USA). P values $<0.05$ were considered significant [12]. Values are expressed as means \pm SD or medians and ranges, depending on the normality of the distribution [12].

\section{Results}

Hemodynamics, dialysis quality and nutritional parameters

Statistical analysis of individual data by the n-of- 1 methodology showed that 20\% albumin increased systolic blood pressure (SBP) in 6 patients ( $\mathrm{p}<0.05$, Wilcoxon test) whereas $4 \%$ gelatin improved SBP in only 3 patients $(\mathrm{p}<$ 0.05 , Wilcoxon test). Albumin infusions increased diastolic blood pressure (DBP) in 4 patients $(\mathrm{p}<0.05$, Wilcoxon test), whereas gelatin improved DBP in only 1 patient ( $\mathrm{p}<0.05$, Wilcoxon test). Weight gain between dialysis sessions was generally similar during the periods in most patients. An increase in the ultrafiltration rate was observed in 5 of the 6 patients whose blood pressure was improved by colloids ( $\mathrm{p}<0.005$, Wilcoxon test) lessening the need for additional dialysis sessions and reducing the difference between the target dry weight and weight measured at the end of the dialysis sessions. Kt/V and the fall in relative blood volume remained stable during the study, whereas ionic dialysance at the end of the dialysis sessions was improved only by albumin infusion $(\mathrm{p}<0.05$, repeated measures ANOVA). These results are extensively analyzed in reference 9 .

\section{Microinflammatory status}

C-reactive protein and haptoglobin levels did not differ between the four periods ( $p>0.05$ repeated measures ANOVA)(Table 2), whereas serum C3 and ceruloplasmin levels were significantly reduced during the albumin period ( $\mathrm{p}<0.05$ non parametric ANOVA, Friedman test followed by Dunn's post test)(Figure 2).

Table 2 Inflammatory parameters during albumin and gelatin infusions

\begin{tabular}{|c|c|c|c|c|c|}
\hline Parameter & $\begin{array}{l}\text { Before } \\
\text { treatment }\end{array}$ & $\begin{array}{l}\text { Albumin infusion } \\
\text { period }\end{array}$ & $\begin{array}{l}\text { Wah-Out } \\
\text { period }\end{array}$ & $\begin{array}{l}\text { Gelatin infusion } \\
\text { period }\end{array}$ & Statistical analyses \\
\hline $\operatorname{CRP}(\mathrm{mg} / \mathrm{l})$ & $7.12 \pm 8.01$ & $9.25 \pm 11.02$ & $6.46 \pm 7.10$ & $4.78 \pm 4.70$ & $\begin{array}{l}p>0.05 \text { at the repeated measures } \\
\text { ANOVA }\end{array}$ \\
\hline $\begin{array}{l}\text { Ceruloplasmin } \\
(\mathrm{g} / \mathrm{l})\end{array}$ & $0.22[0.14-0.34]$ & $0.19[0.13-0.34]$ & $0.23[0.16-0.32]$ & $0.23[0.16-0.33]$ & $\mathrm{p}<0.05$ at the Friedman test \\
\hline C3 (g/l) & $0.97[0.72-1.59]$ & $0.78[0.61-1.29]$ & $0.96[0.71-1.40]$ & $0.96[0.69-1.39]$ & $\mathrm{p}<0.05$ at the Friedman test \\
\hline $\begin{array}{l}\text { Haptoglobin } \\
\qquad(\mathrm{g} / \mathrm{l})\end{array}$ & $1.35 \pm 0.41$ & $1.25 \pm 0.50$ & $1.22 \pm 0.43$ & $1.31 \pm 0.41$ & $\begin{array}{l}p>0.05 \text { at the repeated mesures } \\
\text { ANOVA }\end{array}$ \\
\hline
\end{tabular}




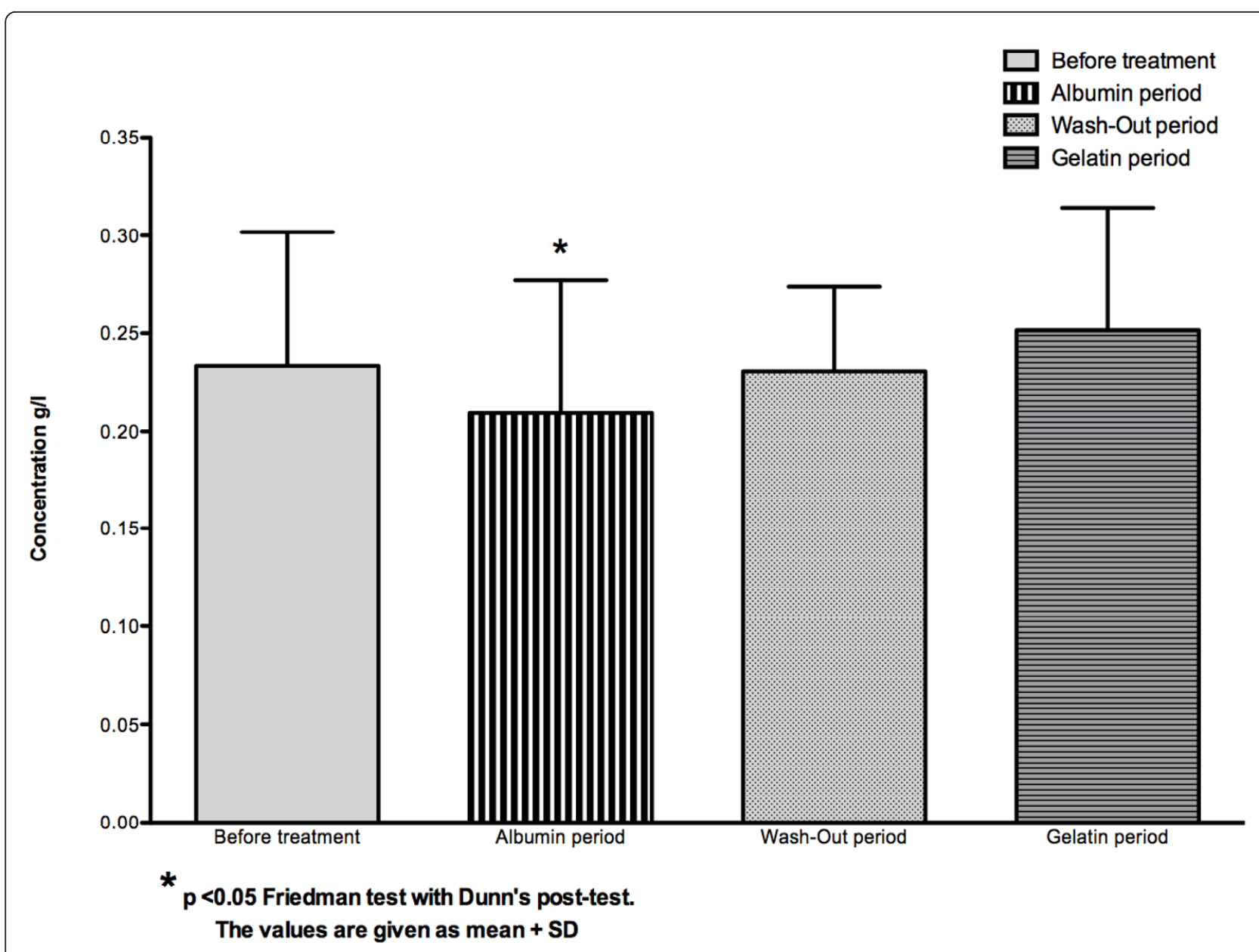

Figure 2 Concentration of serum ceruloplasmin $(g / l)$ in the whole group $(n=10)$.

\section{Oxidative stress}

Plasma total antioxidant power did not differ between the four periods ( $p>0.05$ repeated measures ANOVA)(Table $3)$. Serum hydrogen peroxide values differed between the four periods (Table 3 and figure 3 ) ( $p<0.01$ repeated measures ANOVA) and were significantly lowered during the albumin period, wash-out period and gelatin period ( $\mathrm{p}<$ 0.01 Dunnett's multiple comparisons test)(Figure 3). Serum lipid peroxides were strongly and significantly reduced only during the albumin period ( $\mathrm{p}<0.01$ non parametric ANOVA Friedman test followed by Dunn's post-test) (Table 3 and figure 4). Nitrotyrosine was undetectable at the beginning of the dialysis sessions during the four periods (data not shown). Serum lactoferrin levels before and after dialysis sessions did not differ between the four periods ( $\mathrm{p}>0.05$ repeated measures ANOVA)(Table 3).

\section{Serum cytokines}

IL-1 beta was undetectable both at the beginning and end of the dialysis sessions during each period of the protocol (data not shown). Serum levels of the proinflammatory cytokines IL6, IL8 and TNF alpha did not differ between the four periods of the protocol at the beginning or end of the dialysis sessions ( $p>0.05$ repeated measures ANOVA)(Table 3).

\section{Serum nitrite and nitrate levels}

The sum of serum nitrite and nitrate levels did not differ between the four periods of the protocol at the beginning or end of the dialysis sessions ( $p>0.05$ repeated measures ANOVA)(Table 3).

\section{Discussion}

We recently showed in a pilot single-blind cross-over study, using n-of- 1 trial methodology, that systematic infusion of $20 \%$ albumin or $4 \%$ gelatin during hemodialysis sessions in hypotension-prone patients unresponsive to preventive measures improves hemodynamic parameters (systolic and diastolic blood pressure), increases the ultrafiltration rate and reduces the number 
Table 3 Oxidative stress, serum cytokines, serum nitrites and nitrates during albumin and gelatin infusions

\begin{tabular}{|c|c|c|c|c|c|}
\hline Parameter & $\begin{array}{l}\text { Before } \\
\text { treatment }\end{array}$ & $\begin{array}{c}\text { Albumin } \\
\text { infusion period }\end{array}$ & $\begin{array}{l}\text { Wah-Out } \\
\text { period }\end{array}$ & $\begin{array}{c}\text { Gelatin } \\
\text { infusion period }\end{array}$ & Statistical analyses \\
\hline $\begin{array}{c}\text { Plasma total anti-oxydant power (copper reducing } \\
\text { equivalent microM) }\end{array}$ & $0.23 \pm 0.08$ & $0.26 \pm 0.11$ & $0.27 \pm 0.13$ & $0.22 \pm 0.11$ & $\begin{array}{l}p>0.05 \text { at the repeated } \\
\text { measures ANOVA }\end{array}$ \\
\hline Hydrogen peroxyde $\mu \mathrm{g} / \mathrm{ml}$ & $29.97 \pm 7.3$ & $10.87 \pm 1.9$ & $14.57 \pm 2.5$ & $11.19 \pm 2.4$ & $\begin{array}{l}p<0.001 \text { at the repeated } \\
\text { measures ANOVA }\end{array}$ \\
\hline Lipid peroxides (H202 equivalent) $\mu \mathrm{M} / 1$ & $\begin{array}{c}50 \\
{[13.84-189.5]}\end{array}$ & 7 [7-209.4] & $\begin{array}{c}37.30 \\
{[7-305]}\end{array}$ & $\begin{array}{c}38.20 \\
{[7.82-298.7]}\end{array}$ & $\begin{array}{l}p<0.005 \text { at the Friedman } \\
\text { test }\end{array}$ \\
\hline $\begin{array}{l}\text { Lactoferrin at the beginning of the dialysis session } \\
\qquad(\mathrm{ng} / \mathrm{ml})\end{array}$ & $245.7 \pm 154$ & $199.3 \pm 133$ & $\begin{array}{l}154 \pm \\
36.98\end{array}$ & $153.7 \pm 29.79$ & $\begin{array}{l}p>0.05 \text { at the repeated } \\
\text { measures ANOVA }\end{array}$ \\
\hline Lactoferrin at the end of the dialysis session $(\mathrm{ng} / \mathrm{ml})$ & $\begin{array}{c}159.7 \pm \\
40.52\end{array}$ & $144.5 \pm 48$ & $\begin{array}{c}152.8 \pm \\
31.42\end{array}$ & $154.9 \pm 74.31$ & $\begin{array}{l}p>0.05 \text { at the repeated } \\
\text { measures ANOVA }\end{array}$ \\
\hline IL6 at the beginning of the dialysis session $(\mathrm{pg} / \mathrm{ml})$ & $5.55 \pm 8.19$ & $2.44 \pm 2.82$ & $2.19 \pm 2.87$ & $1.74 \pm 2.51$ & $\begin{array}{l}p>0.05 \text { at the repeated } \\
\text { measures ANOVA }\end{array}$ \\
\hline IL6 at the end of the dialysis session $(\mathrm{pg} / \mathrm{ml})$ & $6.88 \pm 7.56$ & $6 \pm 3.98$ & $4.26 \pm 2.19$ & $5 \pm 3.4$ & $\begin{array}{l}p>0.05 \text { at the repeated } \\
\text { measures ANOVA }\end{array}$ \\
\hline IL8 at the beginning of the dialysis session $(\mathrm{pg} / \mathrm{ml})$ & $\begin{array}{c}32.77 \pm \\
43.79\end{array}$ & $21 \pm 9.89$ & $24 \pm 18$ & $19.83 \pm 13.89$ & $\begin{array}{l}p>0.05 \text { at the Friedman } \\
\text { test }\end{array}$ \\
\hline $\begin{array}{c}\text { TNF } \alpha \text { at the beginning of the dialysis session pg/ } \\
\mathrm{ml}\end{array}$ & $9.85 \pm 10.82$ & $9.13 \pm 5.87$ & $\begin{array}{c}8.04 \pm \\
10.22\end{array}$ & $4.72 \pm 3.59$ & $\begin{array}{l}p>0.05 \text { at the repeated } \\
\text { measures ANOVA }\end{array}$ \\
\hline TNF $\alpha$ at the end of the dialysis session $\mathrm{pg} / \mathrm{ml}$ & $8.33 \pm 7.17$ & $7.59 \pm 4.67$ & $5.40 \pm 2.82$ & $4.51 \pm 2.96$ & $\begin{array}{l}p>0.05 \text { at the repeated } \\
\text { measures ANOVA }\end{array}$ \\
\hline $\begin{array}{l}\text { Serum nitrates }+ \text { nitrites at the beginning of the } \\
\text { dialysis session }(\mu \mathrm{mol} / 1)\end{array}$ & $49 \pm 24.90$ & $50.35 \pm 30.87$ & $53.66 \pm 26$ & $55.35 \pm 28.42$ & $\begin{array}{l}p>0.05 \text { at the repeated } \\
\text { measures ANOVA }\end{array}$ \\
\hline $\begin{array}{l}\text { Serum nitrates }+ \text { nitrites at the end of the dialysis } \\
\text { session }(\mu \mathrm{mol} / \mathrm{l})\end{array}$ & $\begin{array}{c}45.34 \pm \\
27.16\end{array}$ & $48.58 \pm 17.78$ & $47.27 \pm 20$ & $53.70 \pm 34.48$ & $\begin{array}{l}p>0.05 \text { at the repeated } \\
\text { measures ANOVA }\end{array}$ \\
\hline
\end{tabular}

The values are given either as mean \pm SD in case of gaussian distribution or as medium [range] in case of non parametric distribution

of hypotensive episodes [9]. N-of-1 trials, or individualized medication effectiveness tests, are the only way of resolving clinical uncertainty about whether expensive new treatments are truly effective for particular patients. Two provisos must be met: first, the health problem must be a chronic condition in which the outcome measure can be palliated but not removed; second, the effect of treatment should be quantifiable [13,14]. We used the n-of-1 methodology because, in a chronic illness such as renal failure requiring chronic hemodialysis, it can provide an objective basis for identifying treatment outcomes more subtle than death or survival for an individual patient with a rare condition such as refractory dialysis-related hypotension. Moreover, in the case of a new and expensive therapy such as $20 \%$ albumin (200 $\mathrm{ml}$ of $20 \%$ albumin costs 80 euros compared to 4 euros for $4 \%$ gelatin), n-of- 1 trials can furnish powerful evidence for provision on an individual basis, allaying managerial and medical fears as to the cost of frequently ineffective therapies being applied to an expanding atrisk population $[13,14]$.

In this complementary study, we now show that systematic infusions of $20 \%$ albumin and $4 \%$ gelatin in this subset of hemodialysis patients also improve the microinflammatory state and reduce the abnormal oxidative stress. Data on the association between inflammatory status and dialysis hypotension are scarce [15]. Tomita and coworkers compared nine patients with a history of intradialytic hypotension with eight patients without dialysis-associated hypotension and found a correlation between the levels of CRP and IL6 and the maximum percent change in mean arterial pressure over multiple dialysis sessions, suggesting that dialysis hypotension may trigger inflammation [15]. This is consistent with Bergamini et al, who found significant TNF-alpha release during hypotensive episodes [16].

In this pilot study, C3 and ceruloplasmin were significantly lowered during the albumin period but not during the gelatin period. This is consistent with recent studies using experimental models of hemorrhagic shock, which indicated that the type of resuscitation fluid greatly influences proinflammatory responses and especially neutrophil activation and nuclear factorKappa $B$ gene transcription; albumin was found to be the least proinflammatory fluid $[17,18]$. Our patients' use of ultrapure dialysate may explain the low levels of CRP and proinflammatory cytokines (IL6, IL8 and TNF alpha), levels of which have been shown to be greatly influenced by the type of dialysate: indeed, standard dialysate containing endotoxin, but not ultrapure dialysate, has been shown to be a potent inducer of these mediators [19]. The systemic use of cool dialysate, together 


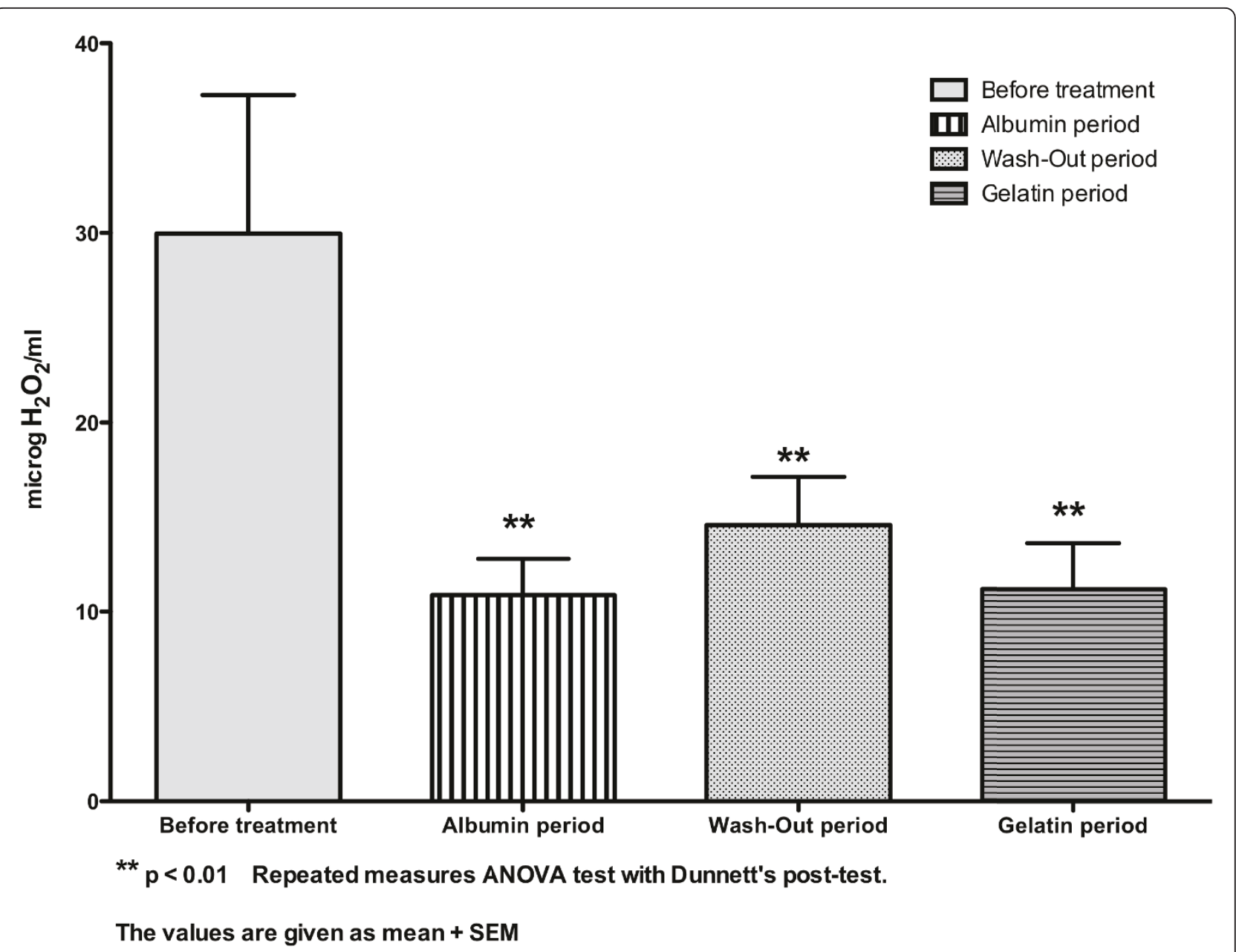

Figure 3 Concentration of serum hydrogen peroxide $\left(\mathrm{microH}_{2} \mathrm{O}_{2} / \mathrm{ml}\right)$ in the whole group $(n=10)$.

with the sodium and ultrafiltration profiles and colloid infusion may also have contributed to these low levels of CRP and pro-inflammatory cytokines [9].

Conversely, ex-vivo data suggest that uremia may increase vascular permeability [20], which may rise acutely during dialysis-associated hypotension via the release of mediators such as adenosine, aimed at preserving perfusion of noble organs [21]; in this setting, albumin may itself influence vascular integrity by binding to the interstitial matrix and subendothelium and by altering the permeability of these layers to large molecules and solutes; these effects may be mediated by the binding of arachidonic acid to albumin and by polynitroxylated albumin, which inhibits xanthine-oxidase-mediated adhesion of human neutrophils to endothelial cells [22].

We found that serum hydrogen peroxide levels were significantly lowered during both the albumin and the gelatin periods, suggesting that the improvement in hemodynamic parameters by colloids reduces oxidative stress related to the ischemia-reperfusion of noble organs that occurs during dialytic hypotension [23]. In addition to classical ischemia-reperfusion mechanism, by analogy with heart failure, entry of bacterial endotoxin during dialysis sessions might result from intermittent underperfusion of the intestine during dialysis-associated hypotension, leading to cardiac stunning and oxidative stress [24-26]. Thus, colloids may improve both systemic and intestinal perfusion and reduce gut ischemia [24-26]. These data also strongly suggest that dialytic hypotension may contribute in various ways to the overproduction of reactive oxygen species seen in end-stage renal failure patients, a multifactorial process mainly related to uremia itself, hemoincompatibility of the dialysis system and trace amounts of endotoxin in the dialysate [27].

In this pilot study, serum lipid peroxide levels were significantly reduced only during the albumin period. This is consistent with data showing that human serum albumin and bovine serum albumin provide protection from lipid peroxidation propagated by 


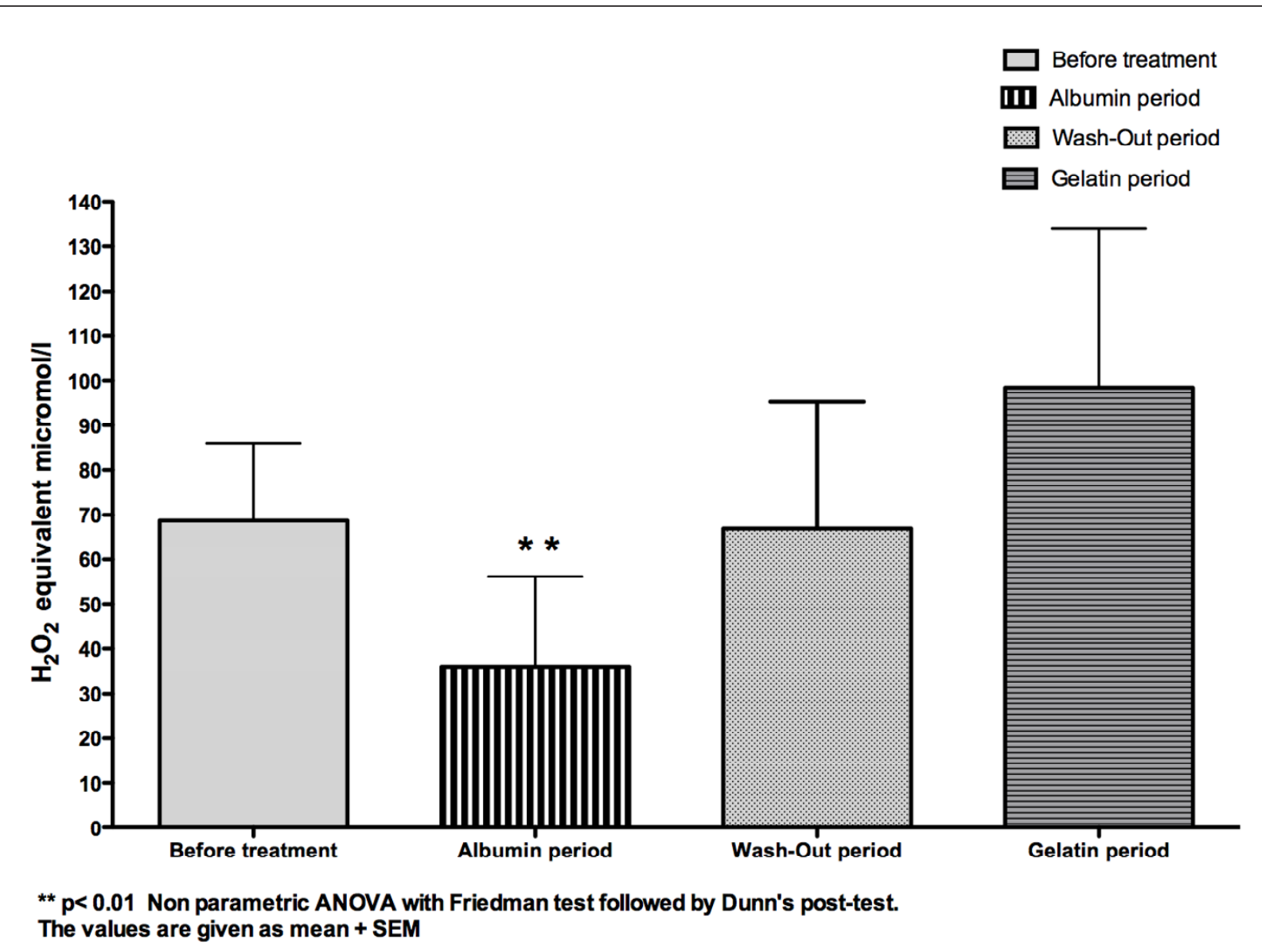

Figure 4 Concentration of the serum lipid peroxides $\left(\mathrm{H}_{2} \mathrm{O}_{2}\right.$ equivalent micromol/l) in the whole group $(n=10)$.

inorganic reactive oxygen species generated from xanthine oxidase/hypoxanthine in artificial systems [28] and that persistent hypoalbuminemia in hemodialysis patients is associated with peroxidation of erythrocyte membranes [29]. Moreover, albumin is the major extracellular source of reduced sulfhydryl groups (thiols), which are avid scavengers of reactive oxygen and nitrogen species; in this way albumin influences the redox balance $[30,31]$.

The main limitations of this pilot study are its small size and the possibility that the difference in ultrafiltration rates between the study periods may have affected the validity of the results for both haemodynamics and inflammation.

\section{Conclusions}

We have previously shown that systematic infusions of $20 \%$ albumin and $4 \%$ gelatin during hemodialysis sessions improve hemodynamic parameters and the ultrafiltration rate in most hypotension-prone dialysis patients unresponsive to usual preventive measures [9]. We observed a parallel improvement in microinflammatory status, which might be related to the decrease in both ischemia-reperfusion of noble organs and oxidative stress. Hyperoncotic $20 \%$ albumin was found to have more potent anti-inflammatory and anti-oxidative properties than $4 \%$ gelatin.

Further well-designed controlled trials with a sufficient number of patients are needed to confirm the efficacy of hyperoncotic $20 \%$ albumin and $4 \%$ gelatin in hypotension-prone dialysis patients.

List of Abbrevations Used

ANOVA: Analysis of variance; CFU: Colony-Forming Unit; CRP: C-reactive protein; DBP: Diastolic Blood Pressure; ELISA: Enzyme-linked immunosorbent assay; IL1 beta: Interleukin 1 beta; IL6: Interleukin 6; IL8: Interleukin 8; Kt/N: Urea fractional clearance; NMWL: Nominal Molecular Weight Limit; NO: Nitric Oxide; SBP: Systolic Blood Pressure; SLE: Systemic Lupus Erythematosus; TNF alpha: Tumor Necrosis Factor alpha

\section{Acknowledgements and Funding}

This work was supported by Association Quincy Recherche Clinique et Thérapeutique, Hôpital Privé Claude Galien and Compagnie Générale de Santé. 


\section{Author details}

${ }^{1}$ Service de Néphrologie et de Dialyse, Hôpital Privé Claude Galien, 20 route de Boussy, 91480 Quincy sous Sénart, France. ${ }^{2}$ Service de Cardiologie, 20 route de Boussy Saint Antoine, 91480 Quincy sous Sénart, France.

\section{Authors' contributions}

GR contributed to the conception and design of the study, statistical analysis, interpreting the data, reporting of the work and writing of the article. MG performed laboratory analysis of microinflammatory status and oxidative stress, statistical analysis, tables and figures. CL performed laboratory analysis of microinflammatory status and oxidative stress, statistical analysis, tables and figures. TB monitored the study in the dialysis center. El contributed to the conception and design of the study and monitored the patients' hemodynamic status. $A B$ contributed to the planning and conduct of the study. All authors read and approved the final manuscript.

\section{Competing interests}

The authors declare that they have no competing interests.

Received: 18 March 2011 Accepted: 20 October 2011

Published: 20 October 2011

\section{References}

1. Leunissen KM, Kooman JP, Van Kuijk W, Van der Sande F, Luik AJ, Van Hoof JP: Preventing haemodynamic instability in patients at risk for intra-dialytic hypotension. Nephrol Dial Transplant 1996, 11(suppl 2):11-15.

2. Schreiber MJ: Clinical Dilemmas in Dialysis: Managing the Hypotensive Patient. Setting the stage. Am J Kidney Diseases 2001, 38(Suppl 4):S1-S10.

3. Palmer BF, Henrich WL: Recent advances in the prevention and management of intradialytic hypotension. J Am Soc Nephrol 2008, 19(1):8-11.

4. Tislér A, Akócsi K, Borbás B, Fazakas L, Ferenczi S, Görögh S, Kulcsar I, Nagy L, Samik J, Szegedi J, Toth E, Wagner G, Kiss I: The effect of frequent or occasional dialysis-associated hypotension on survival of patients on maintenance hemodialysis. Nephrol Dial Transplant 2003, 18(12):2601-2605.

5. The SAFE study investigators: A comparison of albumin and saline for fluid resuscitation in the intensive care unit. New England J Med 2004, 350:2247-2256.

6. Quinlan GJ, Martin GS, Evans TW: Albumin: biochemical properties and therapeutic potential. Hepatology 2005, 41(6):1211-1219.

7. Van Der Sande FM, Kooman JP, Barendregt JN, Nieman FH, Leunissen KM: Effect of saline, albumin or hydroxyethylstarch on blood volume during combined ultrafiltration and hemodialysis. J Am Soc Nephrol 1999, 10:1303-1308.

8. Van Der Sande FM, Luik AJ, Kooman JP, Verstappen V, Leunissen KM: Effect of intravenous fluids on blood pressure course during hemodialysis in hypotensive-prone patients. J Am Soc Nephrol 2000, 11:550-555.

9. Rostoker G, Griuncelli M, Loridon C, Bourlet T, Illouz E, Benmaadi A: A pilot study of routine colloid infusion in hypotension-prone dialysis patients unresponsive to preventive measures. J Nephrol 2011, 24(2):208-217.

10. Chereix EC, Leunissen KM, Jansen JH, Mooy JM, Van Hoof JP: Echography of the inferior cava is a simple and reliable tool for estimation of dry weight in hemodialysis patients. Nephrol Dial Transplant 1989, 4:563-568.

11. Thys DM, Hillel Z, Goldman ME, Mindich BP, Kaplan JA: A comparison of hemodynamic indices derived by invasive monitoring and twodimensionnal echocardiography. Anesthesiology 1987, 67:630-634.

12. Sheskin D: Handbook of parametric and nonparametric statistical procedures. Chapman and Hall, Boca Raton, USA; 2007

13. Price JD, Grimley Evans J: N-of-1 randomized controlled trials ('N-of-1 trials'): singularly useful in geriatric medecine. Age and Ageing 2002, 31:227-232.

14. Jull A, Bennett D: Do n-of-1 trials really tailor treatment. Lancet 2005 365:1992-1994.

15. Tomita M, Malhotra D, Dheenan S, Shapiro Jl, Henrich WL, Santoro TJ: A potential role for immune activation in hemodialysis hypotension. Renal Failure 2001, 23:637-649.

16. Bergamini $S$, Vandelli $L$, Bellei $E$, Rota C, Manfredini $P$, Tomasi A, Albertazzi A, lannone A: Relashionship of asymmetric dimethylarginine to haemodialysis hypotension. Nitric Oxide 2004, 11:273-278.
17. Cantin AM, Paquette B, Richter M, Larivee P: Albumin-mediated regulation of cellular glutathione and nuclear factor kappa B activation. Am J Resp Crit Care Med 2000, 31:1539-1546.

18. Alam HB, Stanton K, Koustova E, Burris D, Rich N, Rhee P: Effects of different resuscitation strategies on neutrophil activation in a swine model of hemorrhagic shock. Resuscitation 2004, 60:91-99.

19. Lonneman G: Chronic inflammation in hemodialysis: the role of contaminated dialysate. Blood Purif 2000, 18:214-223.

20. Harper SJ, Tomson CRV: Bates Do.human uremic plasma increases microvascular permeability to water and proteins in vivo. Kidney Int 2002, 61:1416-1422.

21. Franssen CF: Adenosine and dialysis hypotension. Kidney Int 2006, 69:789-791.

22. Evans TW: Albumin as a drug: biological effects unrelated to oncotic pressure. Aliment Pharmacol Ther 2002, 16(Suppl 5):6-11.

23. Halliwell B: Free radicals, antioxidants and human disease: curiosity, cause or consequence. Lancet 1994, 344:721-724.

24. Sandek A, Bjarnason I, Volkd HD, Crane R, Meddings JB, Niebauer J, Kaira PR Buhner S, Herrmann R, Springer J, Doehner W, Von Haehling S, Anker SD, Rauchhaus M: Studies on bacterial endotoxin and intestinal absortion function in patients with chronic heart failure. Int J Cardiol 2010.

25. Ritz E: Intestinal -renal syndrome: mirage or reality? Blood Purif 2011 31:70-76.

26. Mc Intyre CW, Harrison LE, Eldehni MT, Jefferies HJ, Szeto CC, John SG, Sigrist MK, Burton JO, Hothi D, Korsheed S, Owen PJ, Lai KB, Li PK: Circulating endotoxin: a novel factor in systemic inflammation and cardiovascular disease in chronic kidney disease. Clin J Am Soc Nephrol 2011, 1:133-141.

27. Morena M, Delbosc S, Dupuy AM, Canaud B, Cristol JP: Overproduction of reactive species in end-stage renal disease patients: a potential component of hemodialysis-associated inflammation. Hemodialysis int 2005, 9:37-46.

28. Radi R, Bush KM, Cosgrove TP, Freeman BA: Reaction of xanthine oxidasederived oxidants with lipid and protein of human plasma. Arch Biochem Biophys 1991, 286:117-125.

29. Soejima A, Matsuzawa N, Miyake N, Karube M, Fukuoka K, Nakabayashi K, Kitamoto K, Nagasawa T: Hypoalbuminemia accelerates erythrocyte membrane lipid peroxidation in chronic hemodialysis patients. Clin Nephrol 1999, 51:92-97

30. Hu ML, Louie S, Cross CE, Motchnik, Halliwell B: Antioxydant protection against hypochlorous acid in human plasma. J Lab Clin Med 1993, 121:257-262.

31. Quinlan GJ, Mumby S, Martin GS, Bernard GR, Gutteridge JM, Evans TW: Albumine influence total plasma antioxidant capacity favorably in patients with acute lung injury. Crit Care Med 2004, 32:755-759.

\section{Pre-publication history}

The pre-publication history for this paper can be accessed here: http://www.biomedcentral.com/1471-2369/12/58/prepub

doi:10.1186/1471-2369-12-58

Cite this article as: Rostoker et al:: Modulation of oxidative stress and microinflammatory status by colloids in refractory dialytic hypotension. BMC Nephrology 2011 12:58

\section{Submit your next manuscript to BioMed Central and take full advantage of:}

- Convenient online submission

- Thorough peer review

- No space constraints or color figure charges

- Immediate publication on acceptance

- Inclusion in PubMed, CAS, Scopus and Google Scholar

- Research which is freely available for redistribution 